\title{
CORRESPONDENCE \\ Foliar water uptake changes the world of tree hydraulics
}

npj Climate and Atmospheric Science (2019)2:1 ;

https://doi.org/10.1038/s41612-018-0060-6

Climate change-induced drought events have become more prevalent during recent years, resulting in an increasing number of high-impact studies focussing on this important topic. ${ }^{1-5}$ In their recent review, Choat et al. ${ }^{5}$ provide a thorough assessment of the triggers of tree mortality under drought, but foliar water uptake is only mentioned as a side-note important for arid environments rather than a generic mechanism of general importance. Even worse, most papers focussing on tree hydraulics during drought ignore this mechanism entirely. ${ }^{1-4}$ However, the positive effects of foliar water uptake on tree hydraulics during drought may be substantial and this for a variety of ecological communities ${ }^{6}$ ranging from tropical montane cloud forests ${ }^{7}$ to mangrove $^{8}$ and dryland ${ }^{9}$ ecosystems. Not only may foliar water uptake rehydrate leaves in all environments where leaf wetting events occur, also stems and roots could rehydrate by the redistribution of water absorbed by the leaves. ${ }^{10}$ It has been shown that this redistributed water can release tension on the water column, ${ }^{8}$ enable turgor-driven growth, ${ }^{8}$ may lead to embolism repair ${ }^{11}$ and could delay the increased probability of reaching the critical or lethal water potential threshold leading to tree mortality. However, direct evidence for the latter is still scarce. If occurring, tree survival might be substantially prolonged by tissue rehydration and protection of root structures during fog, dew or rainfall events that do not substantially wet the soil. As such, foliar water uptake is likely essential for the growth and survival of seedlings ${ }^{7}$ and trees with limited access to soil water, such as trees growing in forests with steep slopes, ${ }^{12}$ saline conditions ${ }^{8}$ and shallow rooting species. ${ }^{13}$

The mechanism of foliar water uptake allows trees to partially decouple their leaf water status from soil water availability, ${ }^{11,14}$ thus improving the entire plant water status. ${ }^{15}$ Following leaf wetting events leading to foliar water uptake, turgor of the stomatal guard cells generally improves, thus enabling a favourable gas exchange and preventing carbon starvation. This results in an improved water and carbon balance while a soil water deficit at the root level occurs ${ }^{15}$ and tips the scale within the 'hydraulic failure versus carbon starvation' debate ${ }^{16}$ towards water, as a beneficial carbon supply would be hindered without foliar water uptake during drought events.

Historically, the ecological impact of foliar water uptake has been debated, resulting in the exclusion of foliar water uptake from ecological, hydrological, atmospheric and climatological models. ${ }^{9}$ However, as leaf wetting events on average occur > 100 days per year across biomes, ${ }^{17}$ the importance of including foliar water uptake and other phenomena related to leaf wetting in these models cannot be neglected. This has recently resulted in the first attempt to include foliar water uptake in a mechanistic tree model that enables the description of associated turgordriven growth spurts. ${ }^{8}$ This concept should become the standard to correctly assess the impact of changing rainfall patterns on mangrove tree growth ${ }^{8}$ and tree growth in general. As climate change-induced drought events are predicted to increase, ${ }^{18}$ including foliar water uptake in models becomes more pressing as the relative importance of this mechanism will increase.

In order to lift foliar water uptake out of the scientific side-note area, and to further increase the knowledge of the relevance of foliar water uptake, we recommend researchers to actively focus on this mechanism in drought and tree mortality studies, and incorporate it in individual tree and global vegetation models as implications can be substantial and may both alter the predictions of tree survival under climate change for entire areas and could have a significant impact on the global carbon budget.

\section{DATA AVAILABILITY}

Data sharing not applicable to this article as no datasets were generated or analysed during the current study.

\section{ACKNOWLEDGEMENTS}

This work was supported by the Fund for Scientific Research-Flanders (FWO) through the PhD grant to J.D.M.S

\section{ADDITIONAL INFORMATION}

Competing interests: The authors declare no competing interests.

Publisher's note: Springer Nature remains neutral with regard to jurisdictional claims in published maps and institutional affiliations.

Jeroen D. M. Schreel ${ }^{1}$ and Kathy Steppe ${ }^{1}$ ${ }^{1}$ Laboratory of Plant Ecology, Department of Plants and Crops, Faculty of Bioscience Engineering, Ghent University, Coupure links 653, 9000 Gent, Belgium Correspondence: Jeroen D. M. Schreel (Jeroen.Schreel@UGent.be) or Kathy Steppe (Kathy.Steppe@UGent.be)

\section{REFERENCES}

1. Phillips, O. L. et al. Drought sensitivity of the Amazon rainforest. Science 323 , 1344-1347 (2009).

2. Lewis, S. L., Brando, P. M., Phillips, O. L., Van Der Heijden, G. M. F. \& Nepstad, D. The 2010 Amazon drought. Science 331, 554 (2011).

3. Williams, A. P. et al. Temperature as a potent driver of regional forest drought stress and tree mortality. Nat. Clim. Chang. 3, 292-297 (2013).

4. Staal, A. et al. Forest-rainfall cascades buffer against drought across the Amazon Nat. Clim. Chang. 8, 539-543 (2018).

5. Choat, B. et al. Triggers of tree mortality under drought and forest mortality. Nature 558, 531-539 (2018)

6. Berry, Z. C. C., Emery, N. C., Gotsch, S. G. \& Goldsmith, G. R. Foliar water uptake: processes, pathways, and integration into plant water budgets. Plant. Cell Environ. https://doi.org/10.1111/pce.13439 (2018).

7. Goldsmith, G. R. Changing directions: the atmosphere - plant - soil continuum. New Phytol. 199, 4-6 (2013).

8. Steppe, K. et al. Direct uptake of canopy rainwater causes turgor-driven growth spurts in the mangrove Avicennia marina. Tree Physiol. 38, 979-991 (2018).

9. Breshears, D. D. et al. Foliar absorption of intercepted rainfall improves woody plant water status most during drought. Ecology 89, 41-47 (2008).

10. Breazeale, E. L. \& Mcgeorge, W. T. Exudation pressure in roots of tomato plants under humid conditions. Soil 75, 293-298 (1953).

11. Mayr, S. et al. Uptake of water via branches helps timberline conifers refill embolized xylem in late winter. Plant Physiol. 164, 1731-1740 (2014). 
12. Nadezhdina, N. et al. Trees never rest: the multiple facets of hydraulic redistribution. Ecohydrology 3, 431-444 (2010).

13. Tognetti, R. Trees harvesting the clouds: fog nets threatened by climate change. Tree Physiol. 35, 921-924 (2015).

14. Simonin, K. A., Santiago, L. S. \& Dawson, T. E. Fog interception by Sequoia sempervirens (D. Don) crowns decouples physiology from soil water deficit. Plant Cell Environ. 32, 882-892 (2009).

15. Burgess, S. S. O. \& Dawson, T. E. The contribution of fog to the water relations of Sequoia sempervirens (D. Don): Foliar uptake and prevention of dehydration. Plant Cell Environ. 27, 1023-1034 (2004).

16. McDowell, N. et al. Mechanisms of plant survival and mortality during drought: why do some plants survive while others succumb to drought? New Phytol. 178, 719-739 (2008).

17. Dawson, T. E. \& Goldsmith, G. R. The value of wet leaves. New Phytol. 219, 1156-1169 (2018)

18. Jamieson, M. A., Trowbridge, A. M., Raffa, K. F. \& Lindroth, R. L. Consequences of climate warming and altered precipitation patterns for plant-insect and multitrophic interactions. Plant Physiol. 160, 1719-1727 (2012).
Open Access This article is licensed under a Creative Commons Attribution 4.0 International License, which permits use, sharing, adaptation, distribution and reproduction in any medium or format, as long as you give appropriate credit to the original author(s) and the source, provide a link to the Creative Commons license, and indicate if changes were made. The images or other third party material in this article are included in the article's Creative Commons license, unless indicated otherwise in a credit line to the material. If material is not included in the article's Creative Commons license and your intended use is not permitted by statutory regulation or exceeds the permitted use, you will need to obtain permission directly from the copyright holder. To view a copy of this license, visit http://creativecommons. org/licenses/by/4.0/.

(c) The Author(s) 2019 